\title{
Project Management - The People Make the Difference
}

F. Deloziet

CH2M HILL HanfordGroup, Inc.

To Be Published in:

Project Management Institute Megazine

Date Published:

January 2001

Prepared for the U.S. Department of Energy

Assistant Secretary for Environmental Management

Copyright Licenes

By acceptanca of this article. the publisher and or recipient acknowledges the

U.S. Government's right to retain a nonexclusive. rovelty-fros license in and to any copyright covering this paper

\section{CH2MHILL Hanford Group, Inc.}

Richland, Washington

Contractor for the U.S. Department of Energy

Office of River Protection under Contract DE-AC06-99RL14047 
LEGAL DISCLAIMER

This repart was prepared as an account of work sponsored by an agency of the United States Government. Neither the United States Government nor any agenoy thereof. nor any of their employess, nor any of thsir contractors. subcontractors or their omployess, makes any warrants express or implied, or assumes any legal liability or responsibility for the accuracy. completeness, or any third party's use or the results of such use of any information. apparatus, product, or procsss disclosad, or represents that its use would not infringe privately ownsd rights. Referance herein to any specific commercial product, procsss. or service by trade name, trademark, manufacturer. or otherwise, does not necessarily constitute or imply its endorsement,

fecommendation, or fovoring by the United States

Govsrnmant or any agency thereof or its contractors or subcontractors. The views and opinions of authors expressed herein do not necessarily state or reflect those of the United States Government or any agency thereof.

This report has bssn rsproducsd from ths bast available copy. Available in paper copy.

\section{Chris 3tellexthand \\ Release Approval 0}


CH2M HILL Hanford Group, Inc. manages the high level nuclear waste tanks for the Department of Energy's Office of River Protection, at the Hanford site in southeastern Washington State. The Hanford tanks contain more than 53 million gallons of waste, 200 million curies (three times that released by Chemobyl), and 67 of the 177 tanks have leaked at some time in the past. The current company has been responsible for the tanks since fall 1996.

Previous to 1996, there is a long history of the Hanford tank farms being the bane of DOE Environmental Management. One tank would periodically and spontaneously release large quantities of flammable gas. Another tank, which does not have double containment as now required by law, self-boiled and required the addition of more than 5,000 gallons of water per month to maintain temperatures within the design parameters of the tank. Only a single-wall steel pipe with limited leak detection was available to transfer waste the 7-mile route from the westem-most tank farms to a waste evaporator. The regulators, public, and congress had little confidence that DOE or its contractors h e w the chemical, physical, or nuclear characteristics of the tanks contents. The nuclear safety controls were so complex and varied for different tanks and different operations, that very few employees understood the hazards and the control requirements. In fact, in 1993, congress found it necessary to pass a law restricting the operations of $\mathbf{5 4}$ of the 177 tanks due to safety concerns - these tanks are known as "watch list" tanks.

This was a bleak picture - DOE's most hazardous nuclear waste storage site - and no one really knew what was in the tanks and control measures were akin to bandaids and bailing wire.

This is not the condition today. No tanks spontaneously belch gas above the flammability limit of hydrogen. All tanks have consistent flammable gas controls that are understood by the tank farm workers. A new doubly contained transfer line, with redundant leak detection systems, routinely transports waste across the 7 miles from the west to east tanks. The high-heat tank has been emptied. A new ventilation system services the doubly contained tanks with the highest heat content. The Defense Nuclear Facilities Safety Board, a presidential appointed group that oversees DOE nuclear safety, has declared that the tank contents are sufficiently characterized. The systems and a plan are in place to remove residual pumpable liquids from the non-compliant single-shell tanks by 2004. More than half of the tanks have been removed from the "watch list" and the rest will be removed within the next year. And, a comprehensive plan exists to retrieve the waste, send it to a treatment plant, and close the tank farms.

At this point, you may be saying, "This is a very interesting history of the improvements in an operation. But, why am I reading it in a Project Management publication?"

Every one of these improvements was a project. Each had specific goals to achieve in a specific time frame for specific allocated resources. CH2M HILL Hanford Group has succeeded in these projects using its Safe Project Delivery business philosophy. Safe Project Delivery has three fundamental components. One is a sound project management system including planning, chartering the team, management and customer endorsement of the project, executing the project, managing change and closing the project. 
The second component is an absolute conviction that every accident is preventable. DuPont Safety Solutions was invaluable in training our executives and middle managers to be credible in this area and to truly make a difference. Finally, there is no higher authority than the procedure when operating nuclear facilities. If the procedure cannot be followed, stop and have it changed before proceeding. No one can tell any employee to bypass the procedure - not DOE, the regulators, the employee's supervisor, not even the president of the company. These compile the clear management expectations given to the workers.

The workers are the most important component in successful project management. It is the project manager's job to create an atmosphere that is conducive to high quality and high productivity work. The atmosphere must be one of openness that encourages a free flow of ideas. It must also be an atmosphere where every worker feels an ownership for the success or failure of the project. No worker will allow one of his teammates to fail, because thatjeopardizes the success of the entire project.

The following is a compilation of my personal rules of conduct for getting the best performance from the only asset for most DOE contractors, the people.

1. Assume that the people working on your project know more about how to do their job than you do. Open the door for their ideas.

2. What you, as the project manager, bring to the job is that you probably have survived longer or are higher up in the organization than your workers. This gives you an experience base of what can go wrong that they may not have considered. Offer your team your professional paranoia. The workers plan for project execution. The project manager does the contingency planning.

3. Workers want affirmation from above. If they are doing a good solid job, tell them so and tell them often. People do not tire of genuine complements. Warning - people know when you are not genuine.

4. Don't delay dealing with bad news. It won't get any better tomorrow. This applies to technical failures, personal failures, beyond-your-control events (i.e., the budget is cut), orjust plain mistakes.

5. Tough decisions should not be made by consensus or by majority rule. The tough decisions belong to the manager. Get all the input from your team and other sources. You will never feel like you have all the information you need. But, you have to make the decisions and be accountable. Hiding behind group decisions makes no one accountable.

6. Celebrate. Have fun. Be personal. As you move up in an organization, never forget how much it meant to you to be recognized - with a note or a word or a handshake - by those well above you in the organization.

7. It is relatively easy to get a dozen people to work together as a team motivated toward achieving a goal. The more people that must work together, the more difficult it becomes to motivate them. This is because communications are not as direct, work is more compartmentalized, internal competition may occur, and the manager doesn't know everything that is going on. Once you get over 1,000 people, the person at the top (or maybe the number two) must dedicate 50 to $70 \%$ of his/her time to motivation. Find 
every way you can to communicate and be accessible - all-hands meetings, small group meetings ("Coffee with the President"), letters to the home, walking the shop floor or field or halls, showing up for lower level staff meetings, observing shift turnover, and answering your own mail and own phone to the extent possible. At this point you must personally give up the planning and execution of the work. You must convince those 1,000 people that they are the most important resource to the project or to the company. They are!

8. When someone brings you a problem, ask him or her what he or she wants you to do. Don't hand them a solution. Chances are they know what needs to be done. Theyjust don't feel empowered to make the decision. They will almost always know better what needs to be done than you do. They also will be much more motivated if they "own" the solution.

9. When someone brings you good news, tell him or her, "That's wonderful". If you think it could have been so much better "if only...", save that thought for another time. Let them fully enjoy the success or good fortune. Don't deflate their spirit.

10. Don't ever compromise on what is really important. But, minimize the number of things that you define as really important. For me, the really important is 1) no higher authority than the procedure, 2) every accident is preventable, and 3) every employee complaint or suggestion deserves a response.

11. No matter how high up you are in an organization, have a truly "open door" policy for every single employee. Don't be afraid that you will spend all of your time with trivial problems. If a person brings an issue to the president's office, that issue is very important to that person.

12. Don't accept bad performance or mediocrity. At the first indication of poor performance, confront the person. In a factual, specific and unemotional way, tell them what was wrong. Tell them your expectations. Ask them for a plan to meet your expectations. Poor performance will pull down (demotivate) the rest of the organization if it is tolerated -- in effect, what you are saying is that poor performance is $\mathrm{OK}$ and meets your expectations. You are also doing the right thing for the poor performer - otherwise, how would a poor performer know to try to change, unless someone told him he was off target. While this works most of the time, sometimes the only way to change the person is to change the person.

The conclusion is that with sound project management systems in place and an absolute commitment to treating the people like the important asset they are, great work can be done. CH2M HILL Hanford Group employees are proud of their work and proud of their company. They know that they are making a difference. They are reducing the level of risk to their fellow employees, the public and the Columbia River. They are being responsible stewards of the taxpayer dollars that fund Hanford work.

To the project manager choosing to take the advice in this document, there is a fantastic side benefit. As the president of CH2M HILL Hanford Group, I am working to model the behavior I expect. Lately, and quite unexpectedly, I find that my employees tell me that I am doing a good job. (See item 3 above.) I didn't realize how much I had missed the real-time affirmation-which is difficult to get when you work for a Board of Directors that is over 1,000 miles away. 
For more information on CH2M HILL's Project Delivery Systems, you can read Project Delivery System: A System and Processfor Benchmark Performance, published by CH2M HILL. You also can get a summary at our web site at http://www.ch2m.com/flash/Svcs/ProjDel/ProjDelNav/ProjDelNavFrame.htm. 


\section{Captions for PMI photos}

A piece of equipment is being prepared for installation into a double-shell tank at the Hanford Site. Project teams worked diligently for years to successfully end the tank's periodic releases of flammable, highly radioactive gas.

Construction of Hanford's cross-site waste transfer system required this welder's full concentration. The cross-site transfer lines are more than six miles long and consist of two stainless steel pipes, each surrounded by a carbon steel pipe. It is used to transport radioactive liquid from the site's west tanks to the east tanks and will eventually deliver the waste to a treatment plant.

It takes teamwork to remove and package equipment after sampling activities. Sampling is part of an ongoing program to characterize Hanford's tank waste.

Attention to detail is imperativeas Hanford workers monitor the more than 8,000 instruments that collect data on environmental and worker safety. 


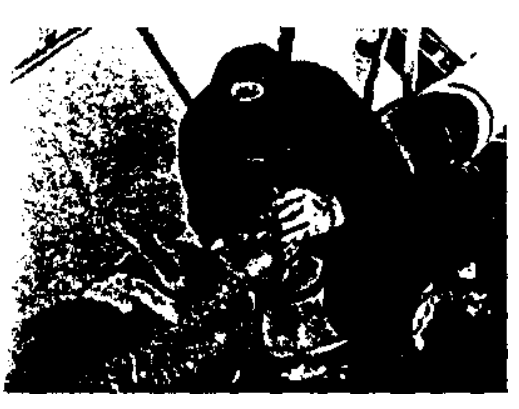

Welding on site-cross transfer. 


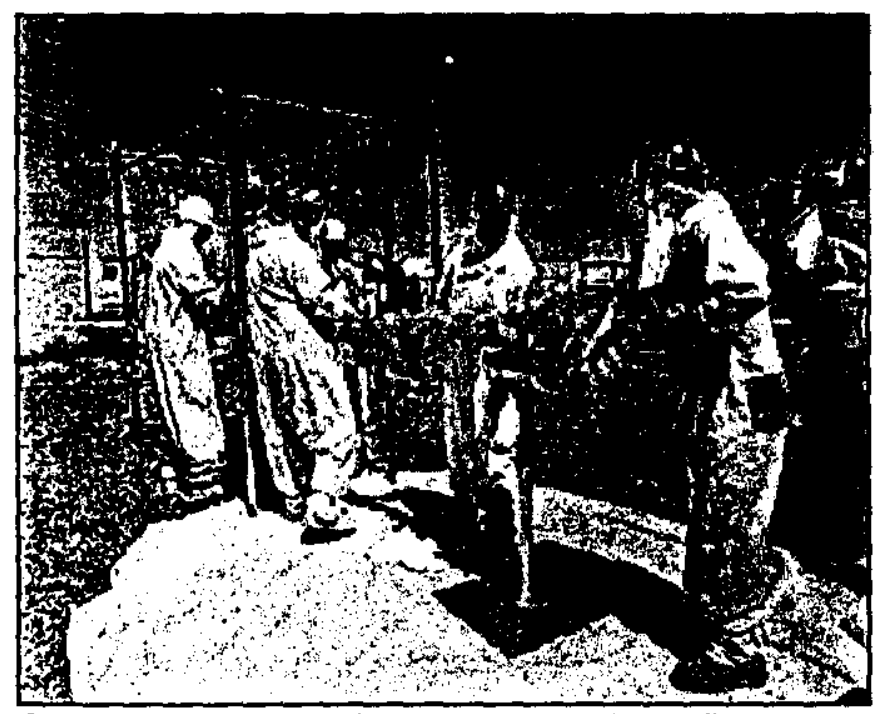

Equipment is removed and packaged after tank sampling activities, part of an ongoing program to characterize Hanford's tank waste. 


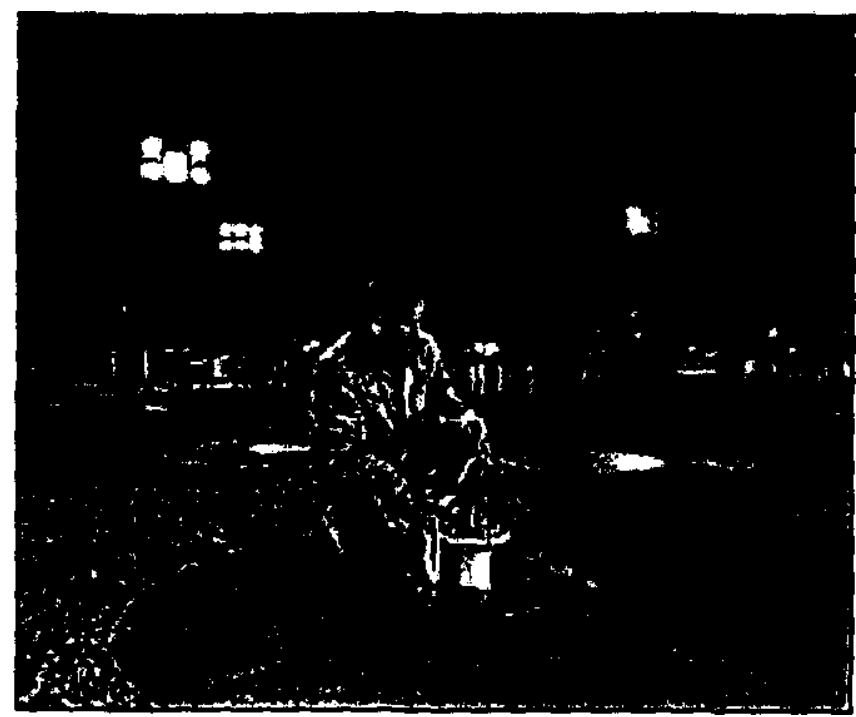

Mor0 than 8,000 instruments that collect data associated with environmental and worker safety are monitored. 


$$
\text { installing coquipment on SY-101 }
$$

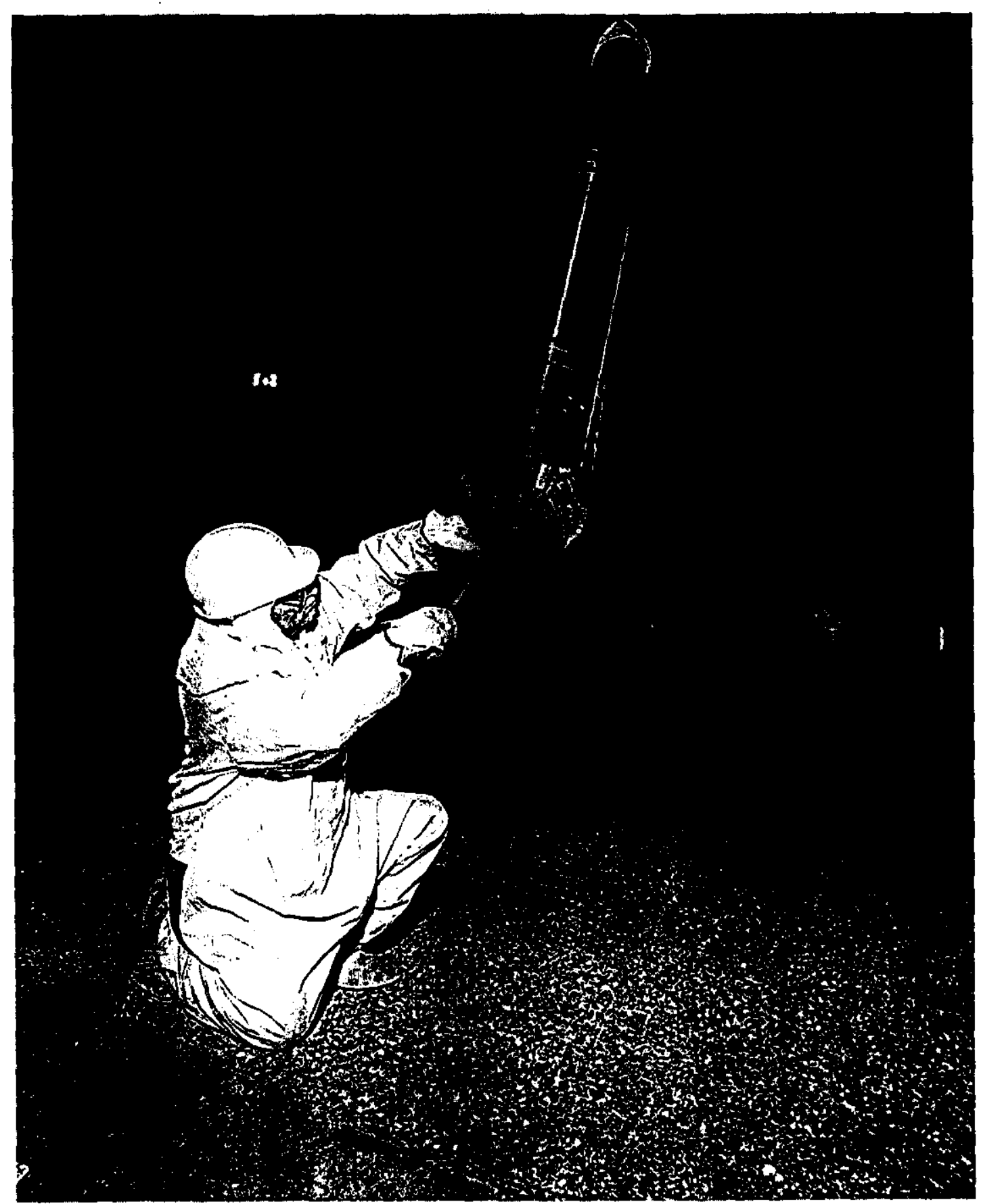

